\title{
Measuring Tourist's Motivations for Consuming Local Angkringan Street Food in Yogyakarta, Indonesia
}

\author{
Mohamad Yusuf* \\ Faculty of Cultural Sciences, Universitas Gadjah Mada, Yogyakarta, Indonesia
}

\begin{abstract}
The purpose of this study was to examine the tourist motivations for consuming local angkringan street food in Yogyakarta city, Indonesia. We distributed questionnaires to 1,514 domestic tourists from several provinces in Indonesia visiting 42 angkringan spots to determine the significance of five different motivations: cultural experience, sensory appeal, media exposure, excitement and health concern. A Confirmatory Factor Analysis was used to analyze the data. A remarkable finding showed that the items belonging to the interpersonal dimension were not grouped in one factor. The Sensory appeal has the highest level of agreement among the tourists, followed by the cultural experience. The health concern has the lowest level of agreement, which is slightly lower than the excitement motivation.
\end{abstract}

Keywords: Angkringan, Food Tourism, Indonesia, Street Food, Types of Tourist Motivation.

\section{INTRODUCTION}

According to the Passengers Exit Survey, approximately 9.86 million foreign tourists visited Indonesia in 2015. This number has significantly increased from 8.04 million in 2012 and 9.44 million in 2014. The increase in the number of tourists visiting Indonesia is in line with the increase in foreign exchange income from the tourism sector from US\$ 9.1 billion in 2012 to US\$12.1 billion in 2015, which equals $10 \%$ of the total GDP [1]. As a consequence, tourism constitutes the third biggest share of the national income after gas and rubber.

For many people in the city of Yogyakarta, which is the second most popular tourist destination in Indonesia after Bali, the tourism sector has become an important factor in their livelihood. In 2015, the tourism sector contributed $19 \%$ of the total government tax revenues [2]. As one of the main tourist destinations in Indonesia, Yogyakarta has long been known as having a great number of traditional foods, for instance, gudeg (young jackfruit curry, cooked with coconut milk), bakpia (a sweet pastry), ronde (hot ginger beverage), etc. which support Yogyakarta's reputation as a centre of traditional Javanese culture. Each type of food has a distinctive flavour and is usually produced and sold by small local businesses that focus on one type of food. An example of the

\footnotetext{
"Correspondence address:

Mohamad Yusuf

Email : myusuf@ugm.ac.id

Address : Faculty of Cultural Sciences, Universitas Gadjah Mada, Jl. Sosiohumaniora, Bulaksumur, Yogyakarta
}

typical culinary industry in Yogyakarta is angkringan. The word angkringan is derived from 'angkring' which means two wooden baskets tied on either side of a bamboo pole that can be carried by shoulder. Besides being a place to eat, angkringan is a place to socialize with friends and other customers.

Our interview found that angkringan first appeared in Yogyakarta around the mid-1960s and then mushroomed in some corners of the city of Yogyakarta. The Statistics Bureau states that there are currently more than 300 angkringan businesses operating in Yogyakarta. Various changes have occurred since the 1960s, such the specific menu items and prices as well as the typical form. While initially, an angkringan was a truly mobile form of street food carried or pushed around neighbourhoods, now each vendor has a specific street-side location with a cart and tent, furnished with chairs and tables. In terms of the menu variety, angkringan currently offers an extra diverse menu, such as sate-satean (sausage satay, nuggets satay, and meatballs satay), nasi kucing (literally "cat's rice") which are small packets of rice with various flavors of chilli sauce, and an assortment of gorengan (fried snacks). Angkringan also offer a variety of traditional drinks, such as coffee joss (coffee with charcoal), wedang uwuh (spicy ginger tea), and iced sticky rice (glutinous rice mixed with sweetened condensed milk). Typical angkringan remain quite cheap with many individual snacks and drinks costing only a few thousand rupiah (ten to fifty cents in USD). However, what used to be considered a cheap place for local lower class people has now become a culinary icon and a tourist attraction in Yogyakarta. Today, in 
addition to the more typical neighbourhood angkringan, there are also angkringan that specifically targeting tourists and middle class customers. For instance, the angkringan in the Tugu train station area, at the North end of the popular Malioboro Street, targets tourists with lower income, while the others in front of the Kedaulatan Rakyat newspaper office is caters to middle class and upper class tourists. There is a perception among Indonesian tourists that a visit to Yogyakarta is not complete without visiting angkringan.

Several studies have shown that tourists spend more than $40 \%$ of their travel budget on food [3]. Some tourists will return to the same destination because of its gastronomy [3]. Obviously, it confirms the connection between food (the culinary sector) and the tourism industry. Culinary development in a certain area is closely related to the development of tourist attractions. In fact, it can be said that the culinary sector has become an effective promotional tool and has an important role in the marketing of a tourist attraction. Many tourists who visit a certain destination are actually primarily driven by the motivation to taste certain local dishes. Culinary development in a destination will affect tourism activities and can provide a significant source of income for local residents [4].

A scale was constructed to measure tourist motivations to consume local food in developed countries in their research on South Korean tourists, and in a comparison between South Korean and British tourists [5]. Obviously, tourists who visit local culinary destinations, such as angkringan, have diverse backgrounds. This study, therefore aims to examine Kim and Eve's scale construction for measuring tourist motivations for consuming local food, and to investigate demographic characteristics (i.e. education level, income level, regional origin, etc.) of tourist visiting angkringan.

In tourism studies, motivation refers to the psychological needs that cause a person to do or not do something, and more specifically to choose to do or not do specific out tourism activities [6]. Motivation is often the main reason for tourists in choosing certain types of destinations. The tourist motivation is fundamental to understanding the tendencies of tourists, as well as to predict, to some extent, travelling habits [7]. Motivation is determined by two factors: the push factor and the pull factor. The push factor is the main reason that drives a tourist to get out of their house in the first place, without taking into account the tourism destination [8]. This factor can be seen as a desire to get out of the routine, adventure, relaxing, etc. The pull factor is the part of motivation that is constituted by the appeal of a destination, introduced through the promotion and information from other media. The push factor is a reaction to daily life, while the pull factor exists in the imagination [8]. The push factors are internal motivations and the pull factors are external motivations [9].

\section{LITERATURE REVIEWS}

Previous research shows that consuming local foods attract people because they are associated with respecting local values, protecting the environment, conserving traditional landscapes and supporting the local economic activities [10]. Also, tourists seek out foods which are regarded as being traditional as part of their quest for authenticity in their travels [11]. There have been few studies that have aimed to analyse motivational factors influencing tourists to visit local culinary attractions. For instance, Kim and Eves have developed a measurement scale for tourist's motivations for consuming local foods. They found that the motivations for food consumption could be categorized into five types, namely: cultural experience, excitement, interpersonal relationship, sensory appeal and health concern [5]. Media influence tourists to consume local foods in Japan [12]. For example, after coverage in the media many tourists visited to try Mizusawa Japanese noodles (udon). She regards this motivation as an extrinsic motivation. The following discussion will discuss these various types of motivation in greater detail.

\section{Cultural experience}

The motivation to learn new things and gain authentic experience is categorized as a cultural motivation [5]. Cultural motivation is not only related to the desire to experience cultural differences, such as music, food, lifestyle, and so on [8]. With regard to food when experiencing new local cuisines, someone also experiences a new culture [13]. Tourists consider local food to represent a unique aspect of a region's culture. Curiosity about a particular region is considered as a thirst or a desire for knowledge and new cultural experiences [14]. Consuming food is a cultural process in that it signifies a cultural meaning to those who consume it [15]. The use of spices is typical to the area, the way of cooking and presentation are also unique. These make local dishes unique markers of regional 
difference that allow tourists to have a different experience in each new place they visit.

\section{Excitement}

Excitement defined as combination of an exciting experience and an escape from routine [5]. In culinary tourism, excitement refers to a need to the experience of tasting a new food or beverage that differs from the tourist's typical fare at home [16]. In addition, feelings of excitement or curiosity will stimulate expectations of food experiences [17]. The excitement motivation is related to emotion, because it involves visitors' affective responses, such as, joy, surprise, and disappointment that are evoked during the course of dining experiences.

\section{Interpersonal relations}

Interpersonal relations are a motivation that relates to the shared social nature of tourism. Mclntosh et al. refers to this as the desire for togetherness that motivates someone to meet other people, spend time with family, and visit family and friends [7]. Fields notes that eating together during the holidays can be regarded as a medium for the reproduction of social relations [13]. More generally, many researchers have observed that food consumption is an important aspect of most social relationships between individuals, or between groups [18] that facilitates social integration and networking [19]. Tourism also functions to bring together members of the family [20]. It is obvious that a tourist destination can be a gathering place for people with similar interests and provides an opportunity for togetherness among family members and other travel companions. This is one of the most important motivations for tourism. By combining food consumption and tourist activities, culinary tourism provides a potentially potent experience of togetherness [21].

\section{Sensory Appeal}

Interesting experience, escaping from the daily routine, wanting to taste different foods, and health reasons, can be categorized together as sensory appeal [5]. From these explanations, sensory appeal associate with reducing physical stress and/or looking for a fresh and pleasant environment. With regard to food tourism, physical motivation can be related to the opportunity to try new and exotic foods. Tasting traditional describe food as a physical experience that involves sensory aspects, such as appearance, taste and smell. The motivation to seek pleasure is an important component of tourists' motivation to engage in risky and adventurous activities that offer unique sensations for every individual [25]. With regard to the pleasure of traditional food consumption, Otis asserts that trying new foods also reflects a desire to engage in something new, namely to try foreign foods that were previously unknown [23]. Some studies have also explained that the feeling of pleasure drives someone to look for food outside the home. Travellers looking for fun are based on the psychological aspect: they visit destinations that are different from the place they stay regularly. The pleasure vacation context should be physically and socially different from the environment in which one normally lives [8].

\section{Health Concern}

Health concern is an important motivational factor influencing tourists' interest in consuming local food [5]. Health is linked to tourists' own well-being and health, rather than relaxation. Interest in health has sparked a global-scale study profiling people's motivation to consume local food. A lifestyle perspective to learn what affects health-related behaviours, including consuming certain foods [24]. Women were more concerned about healthy behaviours than men, and that respondents with greater education and income behaved in ways that were healthier than less educated and less wealthy respondents [24].

\section{Media Exposure}

Media exposure refers to the influence of media on people's decision to visit a certain tourist destination. It is also related to activities of individuals in a society, gathering and sharing online information and knowledge. Obviously, with the current popularity of social media, this has become an important factor in people's tourism choices and is often incorporated into marketing strategies. The effect of media exposure in a study assesses the impact of guide books, websites, and television coverage on tourists' decision to consume Mizusawa udon in Japan [12]. Accordingly, tourists used media to find information before they decided to seek out Mizusawa udon on their travels to know more about the noodle and select a restaurant that would be appropriate for them.

\section{MATERIAL AND METHODS}

The survey was conducted during the touristic peak session from October to December 2015. We distributed surveys to 1,514 local tourists from several provinces in Indonesia who visited 
42 angkringan spots in three main tourist destinations in Yogyakarta, namely: Malioboro, Pakualaman and Kraton areas. From each area, we selected randomly 30-40 tourists. Our preliminary research found that angkringan has become a tourist attraction for visitors to Yogyakarta, one of the top destinations in Indonesia for domestic tourists. In a brief preliminary survey we found that 16 out of 20 respondents visiting angkringan in our research area were tourists from outside Yogyakarta. For the main survey we included all respondents who were tourists from outside of Yogyakarta. The potential respondents were asked whether they were interested in joining the survey. Those who agreed to take part in the survey completed the self-administered questionnaire with help from research assistants. The survey is divided into two parts. The first part is the demographic background, consisting of age, gender, education, place of origin and employment. The second part is specifically about different types of motivation. With choices ranging from totally (1) to fully agree (5), respondents were asked their agreement to different types of motivation: cultural experience, excitement, interpersonal relation, sensory appeal, health concern, and media exposure. The motivation scale [5] supports a five-dimension of motivation and found internal consistency. The scale consisted of 24 items and it was demonstrated to have dimensional distinctiveness and stability, internal consistency, content validity, and convergent validity. In addition, we involved another motivation scale of media exposure [12]. Thus, this study uses six dimensions of motivation scale. In this study, questionnaire was first translated into Indonesian language (Bahasa) and later back-translated into English by the author.

This study used two types of statistical analyses [25]. The first method is a Descriptive Analysis. This method is used to analyze the background characteristics of the tourists visiting angkringan, for instance: age, education level, income level, regional origin, etc. The second is a Confirmatory Factor Analysis. This method was used to examine the construct validity [5] and model of types of tourist motivation [12].

\section{RESULT AND DISCUSSION}

\section{Demographic of Culinary Tourists in Yogyakarta}

The majority of tourists visiting angkringan are young people between $18-39$ years old (93\%). Approximately $74.4 \%$ are those between $18-24$ years old and $18.6 \%$ are at the age of $25-39$ years old. It is also shown in Table 1 that there are an almost equal number of tourists in terms of gender (52.1\% male and $47.9 \%$ female) among the respondents. Respondents visiting angkringan are mainly Senior High School (57\%) and university students (37.3\%), commonly from different provinces in Java Island: Central Java 28\%; East Java 16\%; West Java $12 \%$; and Jakarta $32 \%$. Approximately $9.7 \%$ of respondents are from outside Java. If we connect the employment status of the respondents with the monthly salary, it is obvious that the monthly salary of most respondents is low. About $86.6 \%$ of our respondents receive less than US 250 per month. The reason might be that the income of Senior High School and university students is dependent upon their parents. Although some of them have a part time job and might come from middleupper economic status, but they remain to earn little money.

Obviously, the mentioned findings are interesting if people consider that angkringan business commonly opens in the evening from roughly $6 \mathrm{pm}$ through midnight. This might indicate that Yogyakarta, especially in the three main tourist destinations, in general, is a safe place to hang around in the evening. Another interesting finding with regard to the background characteristics of the respondents is that respondents visiting angkringan are mainly Senior High School and university students. This seems to affirm Yogyakarta as a city of students, in terms of both the most attractive tourist destination among the students, and the number of students studying in Yogyakarta. The Ministry of Higher Education reports that there are 137 higher education institutions located in Yogyakarta. In total, Yogyakarta has approximately 187,714 students, comprised of 105,023 male and 77,691 female students. If we connect the employment status of the respondents with the monthly salary, it is obvious that the monthly salary of most respondents is quite low. There are two reasons that might explain this finding. The first is that this finding confirms the previous finding that most respondents visiting angkringan are students who are not employed yet. The second reason might be that the prices of food at angkringan are more reasonable than other eating places, such as restaurants. Although there is a changing meaning of the angkringan, from local production to tourist consumption, the prices at angkringan are still quite low and, therefore, it is a good place to visit for tourists of limited means. 
Table 1. Demographic Background of Respondents

\begin{tabular}{|c|c|c|c|}
\hline Variable & & Frequency $(n=1545)$ & Percentage(\%) \\
\hline \multirow[t]{4}{*}{ Age } & $18-24$ & 1150 & 74.4 \\
\hline & $25-39$ & 288 & 18.6 \\
\hline & $40-55$ & 76 & 4.9 \\
\hline & $>56$ & 2 & 0.1 \\
\hline \multirow[t]{2}{*}{ Gender } & Male & 789 & 52.1 \\
\hline & Female & 727 & 47.9 \\
\hline \multirow[t]{5}{*}{ Education } & Did not finish elementary school & 2 & 0.1 \\
\hline & Elementary School & 7 & 0.5 \\
\hline & Junior High School & 43 & 2.8 \\
\hline & Senior High School & 881 & 57.0 \\
\hline & University & 579 & 37.3 \\
\hline \multirow[t]{8}{*}{ Place of origin } & Central Java & 432 & 28 \\
\hline & East Java & 251 & 16 \\
\hline & West Java & 187 & 12 \\
\hline & Jakarta & 482 & 32 \\
\hline & Sumatra & 45 & 2.9 \\
\hline & Bali and Lombok & 21 & 1.4 \\
\hline & Kalimantan and Sulawesi & 20 & 1.4 \\
\hline & Others & 107 & 6.9 \\
\hline \multirow[t]{6}{*}{ Employment } & Police/Army & 11 & 0.7 \\
\hline & Private sector & 400 & 25.9 \\
\hline & Government employee & 64 & 4.1 \\
\hline & House wife & 34 & 2.2 \\
\hline & University student & 922 & 59.7 \\
\hline & Others & 56 & 3.6 \\
\hline \multirow[t]{5}{*}{ Monthly salary } & $0-$ USD 75 & 751 & 48.6 \\
\hline & USD $76-150$ & 381 & 24.7 \\
\hline & USD $151-250$ & 190 & 12.3 \\
\hline & USD $251-350$ & 69 & 4.5 \\
\hline & > USD 351 & 44 & 2.8 \\
\hline
\end{tabular}

\section{Comparing Types of Motivation}

An interesting finding came out from our Confirmatory Factor Analysis (CFA) in Table 2. The interpersonal variable from Kim and Eves' types of motivation does not appear in the result of our analysis. Some of the items have low commonality, while the others are grouped in different factors. Eventually, our CFA resulted in five types of motivation according to our respondents, namely: cultural experience, sensory appeal, media exposure, excitement and health concern.

The measurement of cultural experience is related to four aspects: symbolism, feeling and experience, acceptance, and representation. Items related to symbolism, and feeling and experience have the highest factor loading indicating that these two factors were most relevant to the motivation of cultural experience for the tourists in our sample. This results indicates that tourists with cultural motivation perceive angkringan as the symbol of Yogyakarta. By consuming local and traditional cuisine, the tourist adopts the values associated with the local identity symbol [26].
It seems quite clear that cultural experience is an important factor for visiting angkringan, as a cognitive experience. They also have feeling of acceptance. For tourists, eating at angkringan makes them feel as if they were real Yogyakartans. Cultural motivation is also related to feeling and experience; eating at angkringan introduces them to the culture of Yogyakarta. It is also related to representation. Respondents feel that the atmosphere at angkringan reflects the atmosphere of Yogyakarta.

Sensory appeal is related to the appearance, smell and taste of the foods. The tourists visiting angkringan are highly motivated by sensory appeal: to see the appearance of the foods, to smell the foods and to taste the foods. According to the tourists, the food at angkringan looks interesting (appearance); the smell of the food at angkringan is tempting (smell); tourists also visit angkringan because of the taste of the food (taste). This finding confirms that the physical motivation connects tasting traditional food as a physical experience through sensory aspects, such as appearance, taste and smell [5]. Sensory appeal is perceived as the main factor for people in finding new food experiences [27]. The 
measurement of media exposure is related to the influence of media, including social media, the internet and television. Accordingly, respondents visit angkringan after their friends upload pictures on social media; tourists got information about angkringan from the internet; and they are interested in visiting angkringan after seeing coverage on television. Some research projects have indicated the power of media influencing the tourist's motivation visiting a certain destination, including culinary tourism [28]. The measurement of status motivation reveals that this motivation is related to media influence, including social media, the internet and television. The motivation to gain prestige is associated with personal pride, the desire for recognition and attention of others [7]. Similarly, the 2015 UNWTO report one of the characteristics of tourism activities is that tourism is a form of existentialism. It means that tourism is a medium to show others one's existence. Taking pictures while visiting culinary destinations, and posting them on social media is an example for improving the status and pride, which can show a person's identity or differences with others.

Excitement seems to be related to the desire to escape from routine activities. The measurement of this motivation is related to enjoyment and a break from daily routine. Our respondents visit angkringan to enjoy themselves, to break from their daily routine. Tourists spend their free time after other tourism activities at angkringan.

Table 2. Factor Analysis

\begin{tabular}{|c|c|c|c|}
\hline $\begin{array}{c}\text { Types of } \\
\text { Motivation }\end{array}$ & $\begin{array}{l}\text { Factor } \\
\text { loading }\end{array}$ & $\begin{array}{l}\text { Reliability } \\
\text { coefficient }\end{array}$ & $\mathbf{h}^{2}$ \\
\hline Cultural Experience & & .91 & \\
\hline Angkringan is the symbol of Yogyakarta. & .75 & & .57 \\
\hline Eating at angkringan introduces me to the culture of Yogyakarta. & .74 & & .56 \\
\hline Eating at angkringan makes me feel like I am a Yogyanese. & .73 & & .56 \\
\hline The atmosphere at angkringan reflects the atmosphere of Yogyakarta. & .69 & & .51 \\
\hline I will not feel that I am in Yogyakarta unless I enjoy the foods at angkringan. & .66 & & .48 \\
\hline By eating at angkringan, I experience Yogyakarta. & .66 & & .51 \\
\hline How to eat at angkringan represents a unique culture of Yogyakarta. & .65 & & .46 \\
\hline My visit to Yogyakarta would be incomplete unless I visited angkringan. & .64 & & .55 \\
\hline I get more experienced in Yogyakarta if I visit angkringan. & .60 & & .49 \\
\hline I am more aware of Yogyakarta culture after having eaten at angkringan. & .58 & & .46 \\
\hline Sensory Appeal & & .87 & \\
\hline The menu at angkringan looks interesting. & .78 & & .64 \\
\hline Foods at angkringan are tempting me. & .78 & & .65 \\
\hline I am interested in the appearance of foods in angkringan. & .74 & & .58 \\
\hline I like the variety of food at angkringan. & .70 & & .51 \\
\hline The smell of the foods at angkringan is tempting to me. & .67 & & .50 \\
\hline I visit angkringan because of the taste of the foods. & .63 & & .51 \\
\hline I visit angkringan because it offers delicious foods. & .61 & & .48 \\
\hline Media Exposure & & .89 & \\
\hline I visit angkringan after friends uploaded its pictures on social media. & .81 & & .71 \\
\hline I got information about angkringan from the internet. & .76 & & .63 \\
\hline I am interested in visiting angkringan after seeing coverage on television. & .75 & & .61 \\
\hline I find references about angkringan from the Internet. & .75 & & .61 \\
\hline I learned about angkringan through social media. & .75 & & .61 \\
\hline I am interested in visiting angkringan after seeing a celebrity visited angkringan. & .73 & & .56 \\
\hline The media is a reliable source of information about angkringan. & .65 & & .50 \\
\hline Excitement & & .80 & \\
\hline I visit angkringan to enjoy myself. & .72 & & .62 \\
\hline Angkringan is the place to enjoy the time outside my daily routines. & .67 & & .57 \\
\hline I spend my free time at angkringan & .67 & & .57 \\
\hline I visit angkringan after I finish my daily routines. & .65 & & .52 \\
\hline When I visit Yogyakarta, I will definitely go to angkringan. & .49 & & .50 \\
\hline Health Concern & & .76 & \\
\hline The traders maintain the cleanness of their stalls. & .76 & & .63 \\
\hline The traders provide trash cans. & .75 & & .58 \\
\hline The traders cover the food properly. & .74 & & .59 \\
\hline The traders provide hand washing. & .69 & & .56 \\
\hline
\end{tabular}

Notes: Factor Analysis (Paf, Oblimin rotation), commonalities $\left(\mathrm{h}^{2}\right)$, percentage of explained variance, and reliability (Cronbach's alpha) of types of motivation ( $\mathrm{N}=1545)$

Scale: $1=$ Totally disagree; $2=$ Disagree; $3=$ Not sure; $4=$ Agree; $5=$ Fully agree. Explained variance is $55.20 \%$. 
Table 3. Levels of Agreement with Regard to Types of Motivation

\begin{tabular}{llll}
\hline & N & Mean & Standard Deviation \\
\hline Sensory Appeal & 1545 & 3.45 & .69 \\
Cultural Experience & 1545 & 3.40 & .71 \\
Excitement & 1545 & 3.20 & .78 \\
Health Concern & 1545 & 2.98 & .76 \\
Media Exposure & 1545 & 2.46 & .79 \\
\hline
\end{tabular}

Notes: Scale: $1=$ Totally disagree; $2=$ Disagree; $3=$ Not sure; 4= Agree; 5= Fully agree.

Interpersonal relations can be interpreted as an interaction between people socially and emotionally [5]. Visiting angkringan during vacations enables people to distinguish themselves from other people and to interact with others.

As a developing country, health concerns are a significant issue, particularly with regard to food consumption. In this study, hygiene and cleanness are the major factors related to the health concern motivation. Respondents emphasize that angkringan owners should maintain the cleanliness of their stalls. The owners should also provide trash cans and cover the food properly. Another important point of health concern is that the owner should provide a place for hand washing.

\section{Level of Agreement on Types of Motivation}

The sensory appeal (m 3.45; s.d. 0.69) has the highest level of agreement among the tourists, followed by the cultural experience motivation (m 3.40; s.d. 0.71). The media exposure (m 2.46; s.d. 0.79) has the lowest level of agreement among the tourists, which is slightly lower than the health concern (m 2.98; s.d. 0.76). The fact that sensory appeal has the highest level of agreement for tourists visiting angkringan is evident. Most people will visit culinary spots due to their sensory appeal motivation. They primary go to culinary attraction for a delicious meal, eyecaching menu and foods with good smell. Cultural motivation has the second highest agreement among the tourists (Table 3 ).

This is in accordance with the fact that Yogyakarta is famous for its cultural tourist attractions. Visiting angkringan can also be considered as cultural tourism. Culinary tourism is categorized as cultural tourism because food represents a culture of a region and has its own unique features. If we consider the items belonging to cultural motivation, it represents the motivation to learn about local culture [16]. People visiting angkringan are motivated by the willingness to learn about the culture of Yogyakarta. Visiting local eateries, such as angkringan can provide a moral feel-good factor associated with its consumption [11].

\section{CONCLUSIONS}

This research has produced results which have high validity and reliability in understanding tourists' motivation for culinary tourism, so that later they can be used in other studies with the same theme, but with a different location. Based on the findings of our research, there are two aspects that are most important for angkringan in Yogyakarta and perhaps for other street foods that have become tourist attractions: the physical and cultural aspects. According to our results, physical aspects have the highest level of agreement among our respondents. Here three aspects should be taken into account: the appearance, smell and taste of the foods. The motivation with the second highest level of agreement among our respondents was cultural motivation, particularly the aspects of symbolism and local representation.

Indeed, the development of the angkringan business has gone hand in hand with the development of tourism in Yogyakarta. Without a doubt, culinary tourism, such as angkringan should take into account the tourist motivations and background characteristics in order to find suitable marketing strategies.

\section{ACKNOWLEDGEMENT}

This work was supported by the Faculty of Cultural Sciences, Universitas Gadjah Mada, Indonesia.

\section{REFERENCES}

[1] Centre of Statistic. 2016. Tourist visit. Available at: https://www.bps.go.id/Subjek/ view/id/16.

[2] Government Tourism Office Yogyakarta. 2015. Statistik kepariwisataan 2015. Provincial Tourism Office. Yogyakarta.

[3] Kivela, J. J. and J. C. Crotts. 2015. Understanding travelers' experiences of gastronomy through etymology and narration. Journal of Hospitality and Tourism Research 33(2), 161-192. 
[4] Bessiere, J. 2001. The role of rural gastronomy in tourism. In: Roberts, L. and D. Hall (Eds). Rural tourism and recreation: principles to practices. CABI. New York, NY. 115-118.

[5] Kim, Y. And A. Eves, 2016. Measurement equivalence of an instrument measuring motivation to consume local food: a crosscultural examination across British and Korean. Journal of Hospitality and Tourism Research 40(5), 634-652.

[6] Crompton, J. L. and S. L. McKay. 1997. Motives of visitors attending festival events. Annals of Tourism Research 24, 425-439.

[7] McIntosh, R.W., C. R. Goeldner and J. R. B. Ritchie. 1995. Tourism principles, practices, philosophies, $7^{\text {th }}$ Ed. Wiley. New York.

[8] Cromptom, J. 1979. Motivations for pleasure vacation. Annals of Tourism Research 6(4), 408-424.

[9] Yoona, Y. and M. Uysal. 2005. An examination of the effects of motivation and satisfaction on destination loyalty: a structural model. Tourism Management 26(1), 45-56.

[10] Allen, P. and C. Hinrichs. 2007. Buying into 'buy local': engagements of United States local food initiatives. In: Holloway, L., D. Maye and M. Kneafsy (Eds). Constructing alternative food geographies: representation and practice. Elsevier Press. Oxford, UK. 255-272.

[11] Sims, R. 2009. Food, place and authenticity: local food and the sustainable tourism experience. Journal of Sustainable Tourism 17(3), 321-336.

[12] Yagi, M. 2014. Tourist motivation, experience and identity of Udon tourism in Japan: the case study of Mizusawa. Master Thesis. Department of Tourism, Faculty of Education, Humanities and Law, Flinders University, Australia.

[13] Fields, K. 2002. Demand for the gastronomy tourism product: motivational factors. In: Hjalager, A. and G. Richards (Eds). Tourism and gastronomy. Routledge: London. 37-50.

[14] Loewenstein, G. 1994. The psychology of curiosity: a review and reinterpretation. Psychological Bulletin 116(1), 75-98.

[15] Au, N. and Law, R. 2002. Categorical classification of tourism dining. Annals of Tourism Research 29(3), 819-833.

[16] Kim, Y., A. Eves and C. Scarles. 2009. Building a model of local food consumption on trips and holidays: a grounded theory approach. International Journal of Hospitality Management 28(3), 423-431.

[17] Rust, R. T. and R. L. Oliver. 2000. Should we delight the customer? Journal of the Academy of Marketing Science 28(1), 86-94.

[18] Symons, M. 1994. Simmel's gastronomic sociology: an overlooked essay. Food and Food ways 5(4), 333-351.

[19] Fischler, C. 1988. Food, self and identity. Social Science Information 27, 275-292.

[20] Wang, N. 1999. Rethinking authenticity in tourism experience. Annals of Tourism Research 26(2), 349-370.

[21] Lacy, J. and W. Douglass. 2002. Beyond authenticity: the meaning and uses of cultural tourism. Tourist Studies 2, 9-21.

[22] Pizam, A., G. Jeong, A. Reichel, H. van Boemmel, J. M. Lusson and L. Steynberg. 2004. The relationship between risk-taking, sensation-seeking, and the tourist behavior of young adults: a cross-cultural study. Journal of Travel Research 42, 251-260.

[23] Otis, L. 1984. Factors influencing the willingness to taste unusual foods. Psychological Report 54, 739-745.

[24] Uitenbroek, D. G., A. Kerekovska and N. Festchieva. 1996. Health lifestyle behaviour and socio-demographic characteristics. A study of Varna, Glasgow and Edinburgh. Social Science and Medicine 43, 367-377.

[25] Sterkens, C. and M. Yusuf. 2015. Preferences for religious education and intergoup attitudes among Indonesian students. Journal of Empirical Theology 28(1), 49-89.

[26] Dimitrovski, D. and Montserrat CrespiVallbona. 2016. Role of food neophilia in food market tourists' motivational construct: The case of La Boqueria in Barcelona, Spain. Journal of Travel and Tourism Marketing, 1-13.

[27] Pollard, T., A. Steptoe and Wardle, J. 1998. Motives underlying healthy eating: using the food choice questionnaire to explain variation in dietary intake. Journal of Biosocial Science 30(2), 165-179.

[28] Chan, N. L. and B. Denizci-Guillet. 2011. Investigation of social media marketing: How does the hotel industry in Hong Kong perform in marketing on social media websites? Journal of Travel \& Tourism Marketing 28(4), 345-368. 